\title{
FORTY-FIVE YEARS OF CLINICAL LEGAL EDUCATION IN SOUTH AFRICA
}

\author{
MA (Riette) du Plessis*
}

\section{ABSTRACT}

In the fourth century BC, Socrates and Aristotle - and in the thirteenth century AD, Roger Bacon - viewed "induction or experimentation as the sine qua non of all knowledge". In the nineteenth century, John Dewey proposed that true education is derived from reflective life experience, rather than from merely memorising facts. These views, over centuries, still underscore the clinical legal education (CLE) methodology. A comparative analysis indicates the development of legal education and CLE in the USA and South Africa.

This contribution discusses the establishment and evolution of CLE at South African universities from the 1970s, through the client-centred focus during the 1980s, the accreditation of university law clinics by the South African Law Society in 1993, and the establishment of AULAI (now SAULCA), whose primary focus is to promote clinical programmes in South Africa.

In particular, this contribution looks at the development of CLE at the Wits Law Clinic, currently aligned with global best practices in CLE, and at student education

* Associate Professor, School of Law, University of the Witwatersrand. 
and scholarship, whilst assisting the poor and marginalised. The diversity in our multicultural society impacts on students' receptivity to particular forms of CLE, which were accentuated during student campaigns in 2015 to decolonise curricula. The challenges and the processes of decolonising the CLE curriculum may lie in focusing on culture, language, professional ethics and on the clients served by the clinic.

Keywords: Clinical legal education; CLE; university law clinics; clinical programmes; Wits Law Clinic; access to justice; live-client clinic; academic scholarship; decolonisation of the curriculum

\section{Introduction}

It has been argued that ancient Greek philosophers, such as Socrates and Aristotle in the fourth century BC, and medieval philosophers, such as Roger Bacon in the thirteenth century $\mathrm{AD}$, all had the same view regarding education, namely the "induction or experimentation as the sine qua non of all knowledge". ${ }^{1}$ In the nineteenth century, ${ }^{2}$ John Dewey embraced genuine education as being derived from life experience to be discussed and reflected upon, ${ }^{3}$ rather than from merely memorising facts. These views, over centuries, today still underscore the Clinical Legal Education (CLE) methodology.

A comparative analysis indicates the development of legal education and CLE in the United States of America (USA) and in South Africa. The establishment and traditional focus of university law clinics in South Africa are discussed, focusing on the Wits Law Clinic (based at the University of the Witwatersrand) (WLC), and on the University of Pretoria Law Clinic (UPLC). The progression of their CLE programmes and current developments in CLE are discussed against a global backdrop, but with a focus on the South African context.

The diversity of the South African multicultural society impacts on students' receptivity to particular forms of CLE. These were accentuated during a campaign by students and a number of progressive academics in 2015 to decolonise curricula. ${ }^{4}$ The final part of this contribution indicates that the new challenge and the processes of decolonising the CLE curriculum may lie in focusing on culture, language, professional ethics and the clients served by the clinic.

1 Landman 1930: 27. Aristotle described knowledge in three forms, namely theory, productive action and practice.

2 Smith 2004: 727.

3 Dewey 1922: 7 further held that experience without reflection can potentially lead to miseducation or a faculty interpretation of experience.

4 Molefe 2016: 30-37. 


\section{The development of legal education: Acomparative analysis}

\section{The United States of America (USA)}

Prior to the unification of America's northern colonies, ${ }^{5}$ legal education was effected through clerkship by apprentice placement at law firms, subsequently replaced by law schools - known as proprietary law schools - that focused on legal practice in an attempt to remedy the apparent lack of conformity in training at the various law firms. ${ }^{6}$ During the $1820 \mathrm{~s}$, theoretical training was provided exclusively by universities, while practical training was provided by proprietary law schools. ${ }^{7}$ The election of President Jackson, ${ }^{8}$ who focused on anti-elitism and the social upliftment of Man, ${ }^{9}$ caused a decline in legal education, which was only remedied when William Langdell became the dean of Harvard Law School in 1870, separating legal education from the profession. ${ }^{10}$ Langdell introduced the case method of study as pedagogy, defining the study of law as a science, ${ }^{11}$ the ideal being that a law student should be taught to think like a lawyer rather than act like one. This caused much discussion on whether law should be viewed as a science, as opposed to being an art. ${ }^{12}$ Langdell's model entailed the continual study of appeal court cases. ${ }^{13}$ His pedagogy was criticised for failing to teach students the practical application of the law,,${ }^{14}$ and specifically from the start of the realist movement in the 1930s, ${ }^{15}$ when the demand for realistic and

5 Franklin 1990: 56; Steenhuisen 2006: 263.

6 Franklin 1990: 56. By 1800, twenty such schools had been established.

7 Ibid.

8 Ibid; Steenhuisen 2006: 263.

9 Jackson's policies caused educational and apprenticeship policies to be struck down and meant that "the practice of law was opened to those with little or no formal preparation". See Franklin 1990: 57.

10 Ibid.

11 Landman 1930: 18-19 describes the casebook (textbook) method as follows: "The student would familiarize himself with the principles of law included in the assignment. The teacher would quiz the student on its content for a part of the succeeding period and then explain, illustrate, and present problems to the class. This method of instruction imparts the law to the student dogmatically as a system of unified, logically arranged principles of unalterable law." See Finley 2011: 163, who suggests a development of the casebook method by using literature to complement the case method, which should help students gain a more complete understanding and should better prepare them for the practice of law. For a full discussion of the casebook method, see Toller 2010: 21-65 and Konop 1931: 275-283.

12 Spiegel 1987: 581.

13 Barnhizer 1979: 68.

14 See Roach 1994: 673, who refers to a student commenting that "using the Case Method is like studying a forest one tree at a time".

15 Steenhuisen 2006: 264. 
practical teaching methods increased. Between 1920 and the 1940s, a clinical legal education methodology within an in-house clinic start to develop. ${ }^{16}$

\section{South Africa}

In 1652, the Dutch colonialists brought the Roman-Dutch Law from the Netherlands to South Africa, ${ }^{17}$ recognising the customary or indigenous law of the African inhabitants of the Cape colony as a subsidiary and inferior system only to be applied between the inhabitants. ${ }^{18}$ The British assumed control over the colony in 1806 and many aspects of English law were adopted. ${ }^{19}$ The Cape Supreme Court was established in 1828 and new advocates and judges were required to be trained in England. The Cape's hybrid system of law was taken to the other territories by the colonisers and was eventually adopted as the law of the Union of South Africa in 1909. ${ }^{20}$

A Law Certificate, ${ }^{21}$ introduced in the Cape in 1858, was the first South African legal qualification offered. In 1859, the first law school based at a university was opened in Cape Town, where the LLB degree was introduced in $1874 .{ }^{22}$ As university teaching progressed over time, the main form of student instruction was through the lecture-and-textbook method, accompanied by the Socratic dialogue. ${ }^{23}$

In 1973, Professors Kahn and Dugard debated the status of legal education in South Africa, ${ }^{24}$ with Kahn arguing that law schools should continue promoting "academic training". ${ }^{25}$ Dugard argued in favour of the reform of legal education through the introduction of clinical law or legal-aid schemes as educational tools. ${ }^{26}$ These sentiments were echoed by Chaskalson a decade later. ${ }^{27}$

16 Amsterdam 1984: 616.

17 Iya 2001: 356.

18 Ibid.

19 See Greenbaum 2009: 6, where she states that English law "shaped the existing South African procedural law and all branches of commercial law".

20 Idem at 6, 7. The Union of South Africa was formed when the four colonies, namely the Cape, Natal, the Orange Free State and Transvaal, were united as one state.

21 Ibid.

22 Idem at 8.

23 Fedler 1993: 999-1003.

24 Described in McQuoid-Mason 1974: 149.

25 Ibid.

26 Idem at 163.

27 At a legal education conference held at the University of the Witwatersrand in 1983: "Law students can leave a university with an LLB degree without ever having seen a client, without ever having been in court, without knowing how to interview a witness or draft a contract, or prepare an argument or address a court. The result is that law graduates emerge from the university with a theoretical training, but without any basic knowledge of, or practical training directed specifically to, the practice of law. I do not believe that there is any profession other than the law in which students leave university as ill-equipped as this to pursue their chosen career." See Chaskalson 1985: 116. See, also, De Klerk 2006a: 935-939. 


\section{The development of Clinical Legal Education: A comparative analysis}

\section{The United States of America}

The first wave of CLE programmes in the USA started during the late 1890s and early $1900 \mathrm{~s},{ }^{28}$ initially as voluntary student programmes for learning lawyering skills and as access to justice for the poor. Between 1920 and the 1940s, John Bradway and Jerome Frank pursued the cause for a CLE methodology within an in-house clinic. ${ }^{29}$ In 1921, The Carnegie Foundation for the Advancement of Teaching, (Carnegie Foundation) funded a study, called the Reed Report, which identified three components necessary to prepare students for the practice of law, namely general education, theoretical knowledge of the law, and practical skills training. ${ }^{30} \mathrm{By}$ the end of the 1950s, a number of accredited law schools had established CLE programmes with varying standards; many were considered as voluntary. ${ }^{31}$

In 1946, and during the latter part of the first wave of CLE programmes, Edgar Dale developed a learning theory, commonly referred to as the "Cone of Experience", ${ }^{32}$ indicating that learning is best achieved through doing. According to Dale, the least effective method included reading text and listening to lectures. A four-phase learning circle, developed by David Kolb and Roger Fry in the 1970s, during the second wave, expanded on this theory of learning by doing. ${ }^{33}$

The second wave of CLE programmes started in the 1960s and continued until the 1990s. It integrated CLE programmes into the mainstream legal curricula, ${ }^{34}$ catapulted by funding from the Ford Foundation.

The third wave, from the 1990s, saw CLE programmes at various universities advancing at a rapid pace, encouraged by the findings of the 1992 MacCrate Report. ${ }^{35}$ In 2007, the Carnegie Foundation compiled a recommendation report, which included an integrated three-year curriculum that incorporated theory and practice, ${ }^{36}$ prompting all accredited universities in the USA to engage in some form of CLE programme.

28 Bloch 2011: 5

29 Amsterdam 1984: 616.

30 Sonsteng et al 2007: 42.

31 Bloch 2011: 5

32 "In the Cone of Experience, the base of the cone represents the learner as a participant in actual or simulated experience and the top of the cone represents the learner as a mere observer of symbols that represents an event (e.g., reading words on a page)" - see Sonsteng et al 2007: 68.

33 Idem at 72. The four phases include experience, reflection, theory and application. Kolb and Fry also indicated that learning by doing is only effective if what has been learnt is reflected on. This view is supported by Stuckey 2006-2007: 807-838.

34 Bloch 2011: 7. See, also, Sonsteng et al 2007:20.

35 Findley 2006-2007: 306.

36 Sullivan et al 2007 (hereinafter referred to as the "Carnegie Report"). 


\section{CLE programmes in SA}

After law schools introduced full-time legal programmes during the 1970s, some progressive academics began responding to social equality. ${ }^{37}$ This period in the South African history was motivated by the political circumstances, and was marked by very little commitment from the state towards providing legal aid for disadvantaged persons ${ }^{38}$ Law students in particular began to take it upon themselves to bridge the gap. ${ }^{39}$

A number of South African universities established legal aid clinical programmes in the $1970 \mathrm{~s},{ }^{40}$ first at the University of Cape Town (UCT) and soon thereafter at the Universities of the Witwatersrand (Wits) ${ }^{41}$ and Natal. ${ }^{42}$ In 1973, after a conference sponsored by the Ford Foundation, more university legal aid programmes were established..$^{43}$ The primary purpose of these clinical programmes was to increase access to legal services for the poor and the vulnerable, as only limited state legal aid facilities were available at the time. ${ }^{44}$

The opposition to the apartheid government's policies created increased unrest. Hundreds of activists were detained and journalists were banned from certain areas. ${ }^{45}$ Foreign donor support secured the creation of organisations, such as the Legal Resources Centre and the Centre for Applied Legal Studies at Wits, focusing on litigation to confront apartheid. ${ }^{46}$ During the 1980 s, university law clinics assisted the poor, while the more progressive clinics dealt with cases involving breaches of fundamental human rights. ${ }^{47}$ The focus of the clinics at that time was on access to justice, rather than on student education. By 1981, fourteen universities had established law clinics. ${ }^{48}$

37 Kentridge 1974: 87-89.

38 Ibid; Haupt 2006: 229.

39 Haupt 2006: 229.

40 De Klerk 2006a: 930.

41 Initially called the Practical Legal Training Programme (1973); later Practical Legal Studies (1983). Presently, the CLE programme offered at the Wits Law Clinic is known as Practical Legal Studies.

42 De Klerk 2006a: 930. See, also, McQuoid-Mason \& Palmer 2013: 8-9.

43 McQuoid-Mason 1986: 189. See, generally, McQuoid-Mason 1982: 139-163.

44 Haupt 2006: 229. See, also, McQuoid-Mason 2004: 28-51; McQuoid-Mason 2005: 1-16; McQuoid-Mason 2008b: 8-9.

45 De Klerk 2006a: 939.

46 Ibid.

47 Idem at 940.

48 McQuoid-Mason, Ojukwu \& Wachira 2011: 24-25. These include the Universities of Cape Town (1972), the Witwatersrand (1973), Natal (Durban) (1973), Port Elizabeth (1974), Natal (Pietermaritzburg) (1974), Western Cape (1975), Stellenbosch (1975), Durban-Westville (1978), Zululand (1978), Rhodes (1979), the North (1980), Pretoria (1980), South Africa (1981) and Rand Afrikaans University (1981). 
The 1990s saw an increase in legal aid programmes. This was motivated by a number of factors, including an increase in the development of state legal aid systems, ${ }^{49}$ the accreditation of law clinics by the South African Law Society in $1993,{ }^{50}$ funding from the Attorneys Fidelity Fund (AFF) - specifically for the educational development of clinical programmes ${ }^{51}$ - and the establishment of the Association of University Legal Aid Institutes (AULAI), whose primary purpose was to promote clinical programmes in South Africa. ${ }^{52}$

\section{Traditional focus of law clinics and the evolution of CLE programmes}

The idea of access to justice dates back to at least the end of the fifteenth century, with England's King Henry VII ordering judges to assign counsel to the poor in need of help. ${ }^{53}$ During the 1960s and 1970s, progressive lawyers and academics raised the awareness of injustice, indicating that the justice system "was merely a formal right, with little substance and limited practical effect. The reality was that most people rarely engaged with the legal system and those that did were often denied access to representation and advice because of financial reasons". ${ }^{54}$

Globally, universities traditionally structured their CLE progammes with a view to provide access to justice to the poor and marginalised, ${ }^{55}$ defining the CLE programmes as such and underscoring it as an isolated course. ${ }^{56} \mathrm{In}$ his discussion of the experiences of students at Yale University in the 1920s, Bloch notes that " $[t]$ he academic faculty allowed the students to work in the legal aid offices but refused to award academic credit, considering the work to be outside the academic domain". ${ }^{57}$ Earlier, authors did not view CLE as forms of pedagogy or as a teaching methodology that could be incorporated into traditional law school courses. ${ }^{58}$ The

49 The Legal Aid Board provided funding to clinics subject to certain conditions and it increasingly relied on law clinics to provide access to justice. See De Klerk 2006a: 931-940.

50 The Attorney's Act 53 of 1979 was amended to recognise law clinics, allowing the employ of candidate attorneys to complete their articles. See McQuoid-Mason 2000: 123. See, also, Steenhuisen 2006: 264.

51 Since 1988. Steenhuisen 2006: 264; De Klerk 2006a: 931. AULAI was subsequently renamed SAULCA (South African University Law Clinics Association) - see the general website at http:// www.saulca.co.za/home (accessed 5 Oct 2019).

52 De Klerk 2006a: 931. On 30 Jun 1998, the AULAI Trust was formed specifically in response to funding received from the Ford Foundation $(\mathrm{FF})$, who required a legal entity to be established to administer and manage the funding received.

53 See Bloch \& Noone 2011: 153-166 for a discussion on the history.

54 Ibid.

55 Ibid; McQuoid-Mason 1977: 343-358; De Klerk 2006a: 929. For a full discussion, see Bloch 2011: 4-400.

56 Bloch \& Noone 2011: 153-166.

57 Bloch 2011: 4

58 Steenhuisen 2006: 265. 
clinical experience was to simply provide access to justice, allowing students to learn lawyering skills in the process.

Over the last century, a marked change in the definition of CLE occurred, shifting the focus from an access-to-justice driven perspective to teaching students lawyering skills in a live-client clinic. This resulted in an advancement to a more pedagogical definition, establishing CLE as a teaching methodology producing a variety of legal skills and different methods that can be applied to teach these skills. ${ }^{59}$ It was argued that the integration of CLE in the core curriculum of the law school will acknowledge its value as a teaching methodology. ${ }^{60}$

In 1917, William Rowe already had the vision of promoting the integration of clinical programmes into mainstream doctrinal courses, which resembled the current externship programme or hybrid clinic. ${ }^{61}$

Clinics globally grapple with the competing demands of students and clients. The Clinical Legal Education Organisation, United Kingdom (CLEO), holds that the principal aim of clinical programmes is educational and that the student and supervisor competence must dictate the clients to be assisted and in what areas. ${ }^{62}$ This view is echoed in the USA, Australia and South Africa. ${ }^{63}$ There are currently numerous justice centres and legal aid clinics in South Africa that render free legal services to the indigent communities ${ }^{64}$ and provide access to justice; their primary focus is on client services as they are not charged with educational demands. The pressure on university law clinics to service the poor is therefore relieved and they can focus on their primary goal of education. ${ }^{65}$

59 Haupt 2006: 231; Ellmann, Gunning \& Hertz 1994-1995: 6.

60 Du Plessis 2016b: 18. It was further argued that where CLE "remains a separate enterprise from the core teaching of law it is vulnerable to being undermined due to ideological opposition, changing educational fashions or resource cuts". See Hall \& Kerrigan 2011: 30.

61 Barry, Dubin \& Joy 2000: 16-17.

62 Du Plessis 2016b: 22; MacFarlane \& McKeown 2008: 65.

63 Findley 2006-2007: 310, 311; Du Plessis 2016b: 22; Giddings 2010: 297-309; Du Plessis 2008b: 14

64 See Du Plessis 2016b 23: "There are many NGOs, NPOs and government institutions, such as Lawyers for Human Rights, the Legal Resources Centre, Black Sash, Provincial consumer agencies, Ombuds servicing various industries, Attorneys' pro bono centres, ProBono.com, Public Defenders' offices, a myriad of legal call centres attached to insurance companies and Legal Aid South Africa's ('LASA') many justice centres."

65 Ibid. For South Africa, Du Plessis 2008b: 14 states that "[i]n planning the clinical curriculum, clinicians have to define the parameters within which the clinic should operate. Only types of cases that will satisfy the goals of clinical legal education should be considered, and [clinicians] should limit the volume of cases taken on ... to ensure that students derive the best possible training ...." In the USA and the UK, CLE is about the student experience and it should therefore be the student who conducts a case, not the clinician. MacFarlane \& McKeown 2008: 65; Wizner 2001-2002: 1929-1937; Stuckey et al 2007: 195-197. Furthermore, mostly all university law clinics have CLE programmes in place, focusing primarily on student training while providing access to justice. See http://www.saulca.co.za (accessed 5 Oct 2019). 


\section{Current developments in CLE}

Contemporary learning theory for the study of law, also in clinical context, was advanced in the 2007 report of the Carnegie Foundation entitled Educating Lawyers: Preparation for the Profession of Law (Carnegie Report) ${ }^{66}$ Students are required to engage in six tasks if they were to reap the benefit of effective professional education, all of which were applicable to clinical training. ${ }^{67}$ The Carnegie Report recognised that the practical skills of lawyering are most effective in small group settings. ${ }^{68}$

The focus of CLE is increasingly seen as a fundamental aspect of undergraduate law students' education in both developing countries and in Africa. ${ }^{69}$ In focusing on education, clinicians must develop approaches to realise the goal of developing qualified practicing lawyers. ${ }^{70}$ The clinician should therefore not only practise, but also train the student to practise. ${ }^{71}$ When the focus of CLE as a core course in the LLB curriculum is on student training, ${ }^{72}$ the role of clinicians as fully fledged academics is acknowledged. ${ }^{73}$

Kift, an Australian scholar, indicates that legal education reform did not keep pace with the demands of modern practice. Legal graduates enter professional environments very different from those of a decade ago ${ }^{74}$ and these environments are "transformed by external drivers such as globalisation, competitiveness and competition reform, information and communications technology and by a determined move away from

66 For a discussion, see Sullivan et al 2007: passim.

67 These tasks include: "[1.] Developing in students the fundamental knowledge and skills, especially an academic knowledge base and research; 2 . Providing students with the capacity to engage in complex practice; 3 . Enabling students to learn to make judgments under conditions of uncertainty; 4. Teach students how to learn from experience; 5. Introducing students to the disciplines of creating and participating in a responsible and effective professional community; and 6. Forming students able and willing to join an enterprise of public service." See Burch \& Jackson 2009: 57.

68 See Du Plessis 2016b: 110-120 for a discussion of students collaborating in firms in a clinical setting. In a live-client (practical) environment, such as in which CLE is generally taught, students can, in their respective pairs or firms, apply and broaden their knowledge, as well as hone the practical skills taught in the clinical course.

69 Dickson 2000: 33-34; Iya 2000: 13-32.

70 Goode 2000: 223-279.

71 "Practice" in this context refers to the total of the practice in that specific case, excluding the court appearance. The student should, ideally, with the supervision of the clinician, prepare a case from the initial consultation until the case is ready to go to trial. Students in South Africa do not have the right of appearance in courts and there are no student practice rules. For a discussion of student appearances and practice rules in the USA, see Sarkin 1993: 231. Practice rules regarding finalyear law students enrolled in clinical courses representing clients in court were drafted in 1975, and again in 1982 and 1985, but have, to date, never been legislated. For a full discussion, see McQuoid-Mason 2008a: 580-595.

72 As Giddings 2010: 301 explains: "Even when clinics are well-ensconced, it takes a long time to influence the rest of legal education."

73 Findley 2006-2007: 310-311.

74 See Kift 2003: 1-13, who also indicates that "the content, methods and foci of legal knowledge are now also changing so rapidly that, in many areas of practice, the doctrinal law learnt at Law School is no longer current, even on graduation". 
the adversarial system as the primary dispute resolution method". ${ }^{75}$ In 1992 already, the American MacCrate Report indicated that legal education should focus on "what lawyers need to be able to do" as opposed to "what lawyers need to know". ${ }^{76}$ Clinics should therefore identify their primary constituencies. Potential constituencies were identified to include "the public served, students, employers of law graduates, law schools, applicants for admission, taxpayers, alumni, courts, all the role players in the legal profession and the university to which the clinic is attached". ${ }^{77}$ The British scholars, Marson, Wilson and Van Hoorenbeek, hold that students are invigorated when focusing on the needs of the competitive commercial law sector, with leading law firms commending realistic training. ${ }^{78}$ They propose that a clinic should function in the same way as a real law firm, with the students as actors in the legal process, rather than as mere observers, and with the academic ability to extract a theoretical base from the practical experience. This will allow the full benefits of CLE to be extracted, reflected upon, and to be reinvested into the student cohort. ${ }^{79}$

Globally, academic scholarship on CLE is vibrant, with the most recent comprehensive study published by Australian Clinical Legal Education (ACLE). This study is a research-based examination of CLE pedagogy in Australia. ${ }^{80}$ In South Africa, the third edition of a clinical textbook and a textbook on curriculum design and assessment tools in CLE were recently published. ${ }^{81}$

\section{An overview of the development of CLE at the Universities of the Witwatersrand and Pretoria}

\section{Wits Law Clinic (WLC)}

\section{Development from 1973 to 1989}

In 1969, an informal clinical programme was initiated at the University of the Witwatersrand in response to socio-political circumstances. ${ }^{82} \mathrm{~A}$ small number of

75 Ibid.

76 American Bar Association 1992: passim (MacCrate Report).

77 Du Plessis 2016b: 17. See, also, Munro 2002: 231-232.

78 Marson, Wilson \& Van Hoorenbeek 2005: 31.

79 Ibid.

80 Available at http://press.anu.edu.au/publications/australian-clinical-legal-education (accessed 5 Oct 2019), comprising: Clinics and Australian law schools approaching 2020; Australian clinical legal education: Models and definitions; Course design for clinical teaching; Teaching social justice in clinics; The importance of effective supervision; Reflective practice: The essence of clinical legal education; Clinical assessment of students' work; Resourcing live client clinics; and Australian best practice - a comparison with the United Kingdom and the United States.

81 See, in general, Mahomed et al 2015; Du Plessis 2016b; Bodenstein et al 2018; Du Plessis 2019. 82 De Klerk 2006a: 930. 
students of this programme assisted the Johannesburg Legal Aid Bureau, ${ }^{83}$ in addition to managing their own advice office in a so-called coloured township in Riverlea two nights per week ${ }^{84}$ Full-time and final-year students assisting pro deo counsel visited the Supreme Court, the magistrates' courts and the Bantu Affairs Commissioners' court, whereafter the cases were discussed ${ }^{85}$

After the 1973 conference on legal aid in South Africa, ${ }^{86}$ a law clinic with a clinical programme, as an elective credit-bearing course, was established on the Wits campus.This clinic was open during lunch every day of the week for staff and students, and functioned mainly as an advice office. ${ }^{87}$ By 1983, the pedagogy and teaching purposes of the Wits legal aid clinic were confirmed, ${ }^{88}$ although a marked absence of the educational objectives of the legal aid programme was noted. ${ }^{89}$

In 1986, a team of professors visited the University of the Witwatersrand, recommending that a new structure be devised for the clinic "to guarantee the pedagogical goals which justify the clinic's prominence in the new curriculum"..$^{90}$ Between 1986 and 1989, a diverse range of lawyering skills were incorporated in the teaching curriculum of the clinical course, Practical Legal Studies (PLS). ${ }^{91}$

\section{Development from 1990 to 1999}

In 1990, Clinton Bamberger, a PLS teacher at the clinic, called for a refocus of the clinic, to teaching as opposed to mere access to justice, noting that "a teaching law clinic is not an efficient provider of proper service to clients. Teaching is its primary function. Teaching takes time, resources, and the energy from the practice" ${ }^{92}$

83 Dugard 1974: 162.

84 Kahn 1974: 148. Students practised in Riverlea and not in Soweto due to restrictions imposed by the Group Areas Act 41 of 1950 and the Bantu (Urban Areas) Consolidation Act 79 of 1961.

85 Idem at 147, 148. Members of the profession, including judges, magistrates and prosecutors, lectured on the practice of law. Student participation was aimed towards promotion of access to justice, without pedagogical purpose, and their participation carried no credit towards any courses in their law degree.

86 See discussion in par 32 supra.

87 The course was incepted during the period of statutory segregation when black students were only allowed to participate with ministerial permission.

88 See Pretorius 1983: 85-93, who identified goals, teaching methods and students' clinical work, as well as challenges.

89 Idem at 91: "In other words mere participation in the clinic from an educational point of view is not going to give any results unless it is accompanied by a carefully designed teaching programme."

90 Iya 1995: 270.

91 See the Practical Legal Studies course outlines of 1986, 1987 and 1988, archived at the Wits Law Clinic. These include instructions on interviewing and statement taking, drafting, labour law, ethics, dispute resolution and litigation skills.

92 Du Plessis 2016b: 21. Bamberger 1990: 21 observed that "[c]linical faculty and students everywhere are pulled in opposite directions by the demands of service and teaching. The tension is worse in South Africa. There are so few providers of legal assistance for the poor. There are more clients at the clinic's door than can be admitted, if the staff and students did nothing else. The students do not increase the capacity for service. On the contrary, if they are to learn in the experience of law practice, fewer clients can be served". 
However, when the Attorneys Act ${ }^{93}$ was amended in $1993,{ }^{94}$ WLC, like most of the clinics, entered into partnership with the Legal Aid Board (LAB), who placed salaried attorneys at the clinic, ${ }^{95}$ as well as candidate attorneys employed by LAB. The candidate attorneys were assigned to the clinic with a maximum ratio of ten candidate attorneys to one supervisor. ${ }^{96}$ The funding received from LAB promoted the access-to-justice mission of the clinic. Funding from foreign donors was also aimed at the improvement of access to justice. The only external grant for the educational component of the clinic was received from the then Attorneys Fidelity Fund (AFF).${ }^{97}$ Despite a structured clinical course, the focus of the clinic remained largely on access to justice.

In 1995, Iya expressed concern that "[t]he critical issue is that many of the clinical programmes are said to focus their emphasis only on the perspectives of service rather than education" ${ }^{98}$ In 2006, De Klerk warned that "the role that clinics have assumed in access to justice has tainted their image as educational institutions", referring to Woolman, who, in 1997, had already branded university law clinics as "“ersatz legal-aid clinics' that do little reflective teaching". ${ }^{99}$

During the mid to late 1990s, as more justice centres were established by Legal Aid South Africa (LASA), ${ }^{100}$ the focus started to move away from access to justice. ${ }^{101}$ A need developed among the clinicians to specialise, rather than to operate as a general litigation clinic. Towards the end of 1999, the WLC was restructured in specialised units. ${ }^{102}$ Four specialist units were created, namely a family law unit, a labour law unit, a criminal law unit and a law of delict unit, whilst a small general law unit was retained. ${ }^{103}$

\section{From 2000 onwards}

Currently, the live-client clinic operates daily and accommodates walk-in clients, who are served on a first-come-first-serve basis, ${ }^{104}$ resulting in a huge number of

93 Attorneys Act 53 of 1979.

94 These amendments concerned recognising university law clinics accredited by provincial law societies, and allowed them to contract as principals to candidate attorneys, the latter who may appear in the district courts. See McQuoid-Mason 2000: 123-125 for a full discussion.

95 De Klerk 2006a: 931.

96 Ibid.

97 Ibid.

98 Iya 1995: 270.

99 De Klerk 2006a: 942, referring to Woolman, Watson \& Smith 1997: 32.

100 Formerly known as the Legal Aid Board (LAB).

101 See De Klerk 2006a: 947.

102 For a full discussion, see De Klerk \& Mahomed 2006: 306-318.

103 Idem at $311,312$.

104 Du Plessis 2016b: 40. 
consultations and cases taken on. With the focus predominantly on student education and with clinicians teaching in specialised units, ${ }^{105}$ the CLE programme was restructured to accommodate a three-fold pedagogical focus, namely the clinical experience, the classroom component and tutorial components. ${ }^{106}$ The role of the clinician within academia was defined, ${ }^{107}$ culminating in scholarship,,${ }^{108}$ international conference papers and publications, ${ }^{109}$ as well as PhD studies in the field of CLE. ${ }^{110}$ With student education as focus, ${ }^{111}$ educational challenges were identified and addressed, ${ }^{112}$ and client cases suitable for student training were selected. ${ }^{113}$ The CLE curriculum was tested against international standards, ${ }^{114}$ and assessment challenges were identified and addressed. ${ }^{115}$ The challenge of large student numbers culminated in the introduction of collaboration in the form of student firms. ${ }^{116}$

The clinic currently operates in seven specialisation units, each focused on a different subject field, namely that of the law of family, gender and child, labour, property, criminal and delict, refugees, as well as a general litigation unit.

\section{The University of Pretoria Law Clinic}

During May $1980,{ }^{117}$ student volunteers at the University of Pretoria started rendering free legal advice, one night per week for two hours, to the indigent in the so-called coloured community of Eersterus, a township to the east of Pretoria.

105 For discussion of the processes in specialised units, see Du Plessis 2006: 284-294; Du Plessis 2007: 44-63.

106 See Du Plessis 2015c: 64-80 for a full discussion.

107 Du Plessis \& Dass 2013: 390-406.

108 De Klerk 2006b: 244-251; De Klerk 2006a; De Klerk 2007: 95-104; De Klerk \& Mahomed 2006: passim; Du Plessis 2006: 284-294; Du Plessis 2007: passim; Du Plessis 2008a: 121-138; Du Plessis 2008c: 24-33; Du Plessis 2008b: passim; Du Plessis 2009: 91-117; Du Plessis 2011: 25-57; Du Plessis \& Dass 2013: passim; Du Plessis 2013: 17-37; Du Plessis 2014a: 283-297; Du Plessis 2014b: 67-91; Du Plessis 2014c: 73-104; Du Plessis 2015c: passim; Du Plessis 2015a: 2778-2802; Du Plessis 2015b: 312-327; Du Plessis 2016a: 1-22; Du Plessis 2018: 140-162; Du Plessis 2016b: passim; Du Plessis 2019: passim; Mahomed 2008: 53-70; Mahomed \& Kruger 2009: 105-134; Nkosi 2016a: 147-157; Nkosi 2016b: 1-24; Singo 2016: 554-574; Theophilopoulos \& Tuson 2016: 161-180; Singo \& Raymond 2018: 295-313; Dass \& Raymond 2017: $26-42$.

109 Du Plessis 2008a: 121-138; Du Plessis 2014c: 73-104; Mahomed \& Kruger 2009: 105-134; De Klerk 2007: 95-104.

110 See, in general, Du Plessis 2014d: passim; Mahomed 2014: passim.

111 Du Plessis 2015b: 312-327; Du Plessis 2008b: 1-19.

112 Du Plessis 2014c: 73-104.

113 Du Plessis 2008c: 24-33.

114 Du Plessis 2011: 25-57; Du Plessis 2016a: 1-22.

115 Du Plessis 2009: 91-117; Du Plessis 2014a: 283-297; Du Plessis 2014b: 67-91; Du Plessis 2015a: 2778-2802.

116 Du Plessis 2013: 17-37; Du Plessis 2014b: 67-91.

117 Haupt 2006: 232-233. 
The law students referred people and their matters to the LAB. ${ }^{118}$ During September 1980 , the faculty board established a committee, whereafter a constitution for the law clinic was drafted and adopted in 1981. However, by 1984, the original volunteers had graduated and lecturer involvement had not yet materialised. The clinic's constitution ceased to exist when the clinic was incorporated in the Department of Procedural Law and Evidence. The introduction of an elective final-year course in 1987, known as Practical Law, led to the formalisation of the law clinic as part of the law faculty and clinical work became part of the mainstream curriculum. ${ }^{119}$ With the appointment of the first clinical supervisor and later clinical director, the emphasis shifted from client-centred service to student-centred teaching. ${ }^{120}$ This focus was maintained through funding by the then Attorneys Fidelity Fund, who refused that its grants be used for clinical operations. ${ }^{121}$ The 1993 amendment to the Attorneys Act ensured increased manpower with candidate attorneys serving their articles at the clinic. ${ }^{122}$ Specialist units, ${ }^{123}$ such as the Debt Relief Clinic, the Woman and Child Clinic and the Hatfield Community Court Clinic, were introduced in 2001, whilst also retaining a general practice clinic.

The CLE course is currently offered as a final-year elective course in the LLB, with students working initially in firms, later in pairs and, towards the end of the course, individually. ${ }^{124}$ The combination of CLE as an elective course and of clients consulting by appointment only, creates better control and allows for the focus being on students' educational needs.

\section{New challenges: Decolonisation of the curriculum}

The diversity in the SouthAfrican multicultural society impacts on students'receptivity to particular forms of CLE. Students encounter diversity and differences attributed to a "myriad of factors of race, gender, class, culture, religion and language [which] all impact on the way students experience their world, and hence on the context in which their learning takes place". ${ }^{25}$ These were accentuated during a campaign by

$118 \mathrm{Ibid}$. Some law lecturers assisted on an unorganised and informal basis.

119 Idem at 233, 234.

120 Idem at $234,235$.

121 Idem at 237; McQuoid-Mason 1982: 164.

122 Haupt 2006: 237, 238.

123 The factors leading to this development were: “(a) The individual clinician-attorney's preference, experience and knowledge in teaching and practising; (b) the unmet needs of the clients; (c) the tendency of donors to fund specific projects rather than general clinic costs and overheads; and (d) co-operation with other specialist legal aid agencies and the resultant improved system of referrals to and from these agencies." See Haupt 2006: 239.

124 Du Plessis 2016b: 42.

125 Vawda 2006: 296. 
students and a number of progressive academics in 2015 to decolonise curricula. ${ }^{126}$ Heleta agrees that, since the end of the apartheid system in 1994, curricula at most South African universities have not considerably changed and that they remain largely Eurocentric. ${ }^{127}$ The current challenge facing university law clinics is the decolonisation of the CLE curriculum. Much has been written on decolonisation. ${ }^{128}$ For purposes of this contribution, however, the reference to decolonisation is merely to identify and suggest ways in which the process of decolonisation can commence.

\section{Application of the CLE methodology to diversity challenges}

The pedagogy of the CLE methodology, focusing on skills and the practical application of the law, comprises of three basic components, namely clinic duty, classroom teaching and student tutorial sessions with their clinicians. ${ }^{129}$ In addressing the diversity challenges, it is submitted that clinics should focus on culture, language, professional ethics and the clients served by the clinic.

\section{Culture and language}

It was indicated that culture "is not something static and immutable, but is rather moving, dynamic [and] flexible" 130 and that language and culture play a large role in preparing students to enter the profession. ${ }^{131}$ Language controls thought and actions, and people from different cultures who speak different languages will see the universe and respond to it differently; they will not perceive the same reality, unless they have a similar culture. ${ }^{132}$ Students should be grouped in student firms that reflect different cultures and languages, and they should be encouraged to consult with clients comprising a variety of cultures and languages.

126 Molefe 2016: 32

127 Heleta 2016: passim.

128 To name but a few: Molefe 2016: passim; Heleta 2016: passim; Zulu 2017: passim; Smith \& Tvaringe 2018: 41-43; Davis 2015: 172-188; Quinot 2012: 411-433; Anonymous 2017: passim; Letsekha 2013: 5-18; Naidoo 2016: passim; Sayed, Motala \& Hoffman 2017: passim; Le Grange 2014: passim; Le Grange 2014: 1283-1294; Modiri 2015: 224-273; Mnyongani 2009: 122-134; Murove 2005: 339-347.

129 Du Plessis 2016b: 26

130 Smith \& Tvaringe 2018: 42.

131 The view is expressed that Western philosophy embraces individual autonomy, whereas African philosophy focuses its reality on the whole. These two different views have an effect on students entering the profession, as Western norms may not be easily embraced by all.

132 Mnyongani 2009: 124. 


\section{Professional ethics}

Researchers identified a link between culture and ethics, acknowledging the role of culture in informing someone's sense of morality and ethics. ${ }^{133}$ In understanding professional ethics, Mnyongani suggests that the profession "embark on a journey of 'decolonising' their minds", by debating what it means to be African in a profession with a Western approach, ethos and orientation. ${ }^{134}$

Professional ethics is developed as a skill in clinical courses. The CLE methodology promotes an understanding of ethics on a deeper level, where a student is not limited to understanding a theoretical ideal. In the sheltered clinical environment, students will be able to interrogate the impact of their decisions, specifically in relation to their clients and the legal profession, affording them the opportunity to develop their professional identities and to consider their roles within the legal profession. ${ }^{135}$

\section{Clients of the clinic}

Modiri, in discussing poverty in South Africa, opines that the architecture, framework and logic of colonialism-apartheid remain, despite considerable changes to the country's laws. ${ }^{136}$ Clients frequenting university law clinics mainly comprise of the indigent in the community, who often live in abject poverty. ${ }^{137}$ Not only are the clients poor, but they may also represent communities where their cultures differ from those of the students who represent them.

Modiri further indicates that the poor are marginalised and are often dependent on a variety of welfare services where they may be treated arbitrarily. ${ }^{138}$ For these purposes, university law clinics may be viewed as welfare services, and clinicians and students should deal with clients' matters meticulously, recognising that poverty should be understood as a problem of moral recognition. ${ }^{139}$ Ultimately, clinics

133 Murove 2005: 339.

134 See Mnyongani 2009: 133-134, who considers the African ethical components to be on the periphery due to mainstream voices ignoring the would-be contributions of African values. $\mathrm{He}$ holds that African values, which have been relegated to the periphery of the profession, should be considered when making these choices, whilst acknowledging the context within which it operates.

135 Giddings 2013: 59-61.

136 Modiri 2015: 225.

$137 \mathrm{Du}$ Plessis 2016b: 136. The typical profile of a clinic client was described by De Klerk 2007: 97 as "when consulting, clinic clients 'tend to present to the clinic lawyer a rather large package of problems, half of which have nothing to do with the law and the other half so intertwined with poverty that their actual legal problems are often very hard to extract' and '(f)ormulating the mandate is only half the battle won"'.

138 Modiri 2015: 233.

139 Idem at 242. Modiri concludes that the "conditions of powerlessness, marginalisation and cultural imperialism tend to affect Blacks irrespective of their class or position" (at 239). 
representing the poor must strive to empower their clients to be ethically and politically self-representing and self-defining. ${ }^{140}$

\section{Conclusion}

A comparative analysis shows the development of legal education and CLE in the USA and in South Africa, and tracks the progression of CLE programmes at South African university law clinics.

The contribution discusses the evolution of clinical programmes at South African universities from the 1970s, through the client-centered focus during the 1980s, the accreditation of university law clinics by the South African Law Society in 1993 and the establishment of AULAI (now SAULCA), ${ }^{141}$ whose primary focus was to promote clinical programmes in South Africa. Specific attention is paid to the development of CLE at the WLC, currently aligned with global best practices in CLE, and with a focus on student education and scholarship, whilst assisting the poor and the marginalised.

It is suggested that the process of decolonising the CLE curriculum may commence by focusing on culture, language, professional ethics and on the clients served by the clinic.

\section{Bibliography}

American Bar Association (1992) "Legal education and professional development-An educational continuum" (Chicago) ("MacCrate Report") available at https://www.americanbar.org/ content/dam/aba/publications/misc/legal_education/2013_legal_education_and_ professional_development_maccrate_report).authcheckdam.pdf (accessed 5 Oct 2019)

Amsterdam, AG (1984) "Clinical legal education - A 21st-century perspective" J of Legal Education 34(4): 612-618

Anonymous (2017) "Decolonising the curriculum: Stimulating debate" CHE Briefly Speaking 3: 1-12 available at $h t t p: / / w w w . c h e . a c . z a /$ sites/default/files/publications/BrieflySpeaking\%20 \%283\%29\%20Curriculum\%20decolonisation.pdf (accessed 5 Oct 2019)

Bamberger, C (1990) "The practical legal studies course: Now and the future. Memorandum to the School of Law on the activities of the Wits Law Clinic" in MA Du Plessis, (ed) Clinical Legal Education: Law Clinic Curriculum Design and Assessment Tools (Claremont, South Africa): 21

Barnhizer, DR (1979) "The clinical method of legal instruction: Its theory and implementation" J of Legal Education 30: 67-148

140 Van Marle 2002: 299-308.

141 AULAI was subsequently renamed as SAULCA (South African University Law Clinics Association) - see their website at $h t t p: / / w w w . s a u l c a . c o . z a / h o m e$. 


\section{FORTY-FIVE YEARS OF CLINICAL LEGAL EDUCATION IN SOUTH AFRICA}

Barry, MM, JC Dubin \& PA Joy (2000) "Clinical Education for the millennium: The third wave" Clinical LR 7: 16-17 available at https://ssrn.com/abstract=2548228 (accessed 5 Oct 2019)

Bloch, F (ed) (2011) The global clinical movement - Educating lawyers for social justice (Oxford)

Bloch, F \& MA Noone (2011) "Legal aid origins of clinical legal education" in F Bloch (ed) The Global Clinical Movement - Educating Lawyers for Social Justice (Oxford)

Bodenstein, J et al (2018) Law Clinics and the Clinical Law Movement in South Africa (Durban)

Burch, K \& CF Jackson (2009) "Creating the perfect storm: How partnering with the ACLU integrates the Carnegie Report's three apprenticeships" John Marshall LJ 3: 51-104

Chaskalson, A (1985) "Responsibility for practical legal training” De Rebus 207: 116-117

CLEO (2016) "Model standards for live-client clinics" in MA du Plessis (ed) Clinical Legal Education: Law Clinic Curriculum Ddesign and Assessment Tools (Claremont, South Africa)

Dass, D \& A Raymond (2017) “A consideration of the employment rights of asylum seekers and refugees within South Africa as contextualised by the Watchenuka and Discovery Health judgments" Industrial LJ 38: 26-42

Davis, D (2015) "Legal transformation and legal education: Congruence or conflict? Part ii: Reflections on Justice Langa's court and philosophy" Acta Juridica 1: 72-188

De Klerk, W (2006a) "University law clinics in South Africa" SALJ 122(4): 929-950

De Klerk, W (2006b) "Integrating clinical education into the law degree: Thoughts on an alternative model" De Jure 39(2): 244-251

De Klerk, W (2007) "Unity in adversity: Reflections on the clinical movement in South Africa" International J of Clinical Legal Education 1: 95-104

De Klerk, W \& S Mahomed (2006) "Specialisation at a university law clinic: The Wits Experience" De Jure 39(2): 306-318

Dewey, J (1922) Democracy and Education. An Introduction to the Philosophy of Education (New York)

Dickson, J (2000) "Clinical legal education in the 21st century: Still educating for service?" International J of Clinical Legal Education 1: 33-46

Dugard, CJR (1974) “A review of South African legal education” in D Mcquoid-Mason (ed) Legal Aid in South Africa Proceedings of a conference held in the Faculty of Law, University of Natal, Durban, from 2-6 July 1973: 160-165

Du Plessis, MA (2006) “A consumer clinic as a specialised unit” De Jure 2: 284-294

Du Plessis, MA (2007) “Access to justice outside the conventional mould: Creating a model for alternative clinical legal training" J for Juridical Science 32(1): 44-63

Du Plessis, MA (2008a) "Clinics meeting particular student and community needs: A South African perspective” Griffith LR 17(1): 121-138

Du Plessis, MA (2008b) "Closing the gap between the needs of students and the community they serve" J for Juridical Science 33(2): 1-19

Du Plessis, MA (2008c) "Divorce: Achieving social justice through clinical legal education" J for Juridical Science Special Issue: 24-33

Du Plessis, MA (2009) “Assessment challenges in the clinical environment” J for Juridical Science 34(2): 91-117 


\section{MA (RIETTE) DU PLESSIS}

Du Plessis, MA (2011) “Clinical legal education: Planning a curriculum that can be assessed" J for Juridical Science 36(2): 25-57

Du Plessis, MA (2013) “Clinical legal education: The challenge of large student numbers” J for Juridical Science 38(2): 17-37

Du Plessis, MA (2014a) "Reflective journals as an assessment method in clinical legal education" De Jure 47(2): 283-297

Du Plessis, MA (2014b) “Clinical legal education: The assessment of student collaboration and group work” J for Juridical Science 39(2): 67-91

Du Plessis, MA (2014c) "Student assessment in CLE: The challenge of variances in education and experience" African J of Clinical Legal Education and Access to Justice 3: 73-104

Du Plessis, MA (2014d) Assessment Methods in Clinical Legal Education (PhD, University of the Witwatersrand)

Du Plessis, MA (2015a) “Clinical legal education models: Recommended assessment regimes" PER 18(7): 2778-2802

Du Plessis, MA (2015b) “Clinical legal education: Determining the mission and focus of a university law clinic and its required outcomes, skills and values” De Jure 48(2): 312-327

Du Plessis, MA (2015c) "Clinical legal education: Identifying required pedagogical components" $J$ for Juridical Science 40(1 \& 2): 64-80

Du Plessis, M (2016a) "Designing an appropriate and assessable curriculum for clinical legal education" De Jure 49(1): 1-22

Du Plessis, MA (2016b) Clinical Legal Education: Law Clinic Curriculum Design and Assessment Tools (Claremont, South Africa)

Du Plessis, MA (2018) “Clinical legal education: Interviewing skills” De Jure 1: 140-162

Du Plessis, MA (2019) Effective Legal Interviewing and Counselling (Claremont, South Africa)

Du Plessis, MA \& D Dass (2013) "Defining the role of the university law clinician" SALJ 130(2): 390-406

Ellmann, S, I Gunning \& R Hertz (1994-1995) “Why not a clinical lawyer journal?” Clinical LR 1: 1-7

Fedler, J (1993) "Legal education in South Africa" Oregon LR 72: 999-1003

Findley, KA (2006-2007) "Rediscovering the lawyer school: Curriculum reform inWisconsin" Wisconsin International LJ 24: 295-333

Finley, GD (2011) "Langdell and the Leviathan: Improving the first-year law school curriculum by incorporating Moby-Dick" Cornell LR 97: 159-190

Franklin, N (1990) "The clinical movement in American legal education” Natal University Law and Society Review 2: 55-68

Giddings, J (2010) "Bridging different interests: The contributions of clinics to legal education" in FS Bloch (ed) The Global Clinical Movement: Educating Lawyers for Social Justice (Oxford): 297-309

Giddings, J (2013) Promoting Justice through Clinical Legal Education (Justice Press, Australia)

Goode, VM (2000) "There is a method(ology) to this madness: A review and analysis of feedback in the clinical process" Oklahoma LR 53: 223-279 


\section{FORTY-FIVE YEARS OF CLINICAL LEGAL EDUCATION IN SOUTH AFRICA}

Greenbaum, L (2009) “A history of racial disparities in legal education” John Marshall LJ 3: 1-19

Hall, J \& K Kerrigan (2011) "Clinic and the wider law curriculum" International J of Clinical Legal Education 15: 25-37

Haupt, FS (2006) "Some aspects regarding the origin, development and present position of the University of Pretoria Law Clinic" De Jure 39(2): 229-243

Heleta, S (2016) "Decolonisation of higher education: Dismantling epistemic violence and Eurocentrism in South Africa" available at https://thejournal.org.za/index.php/thejournal/ article/view/9/31 (accessed 5 Oct 2019)

Iya, PF (1995) "Addressing the challenges of research into clinical legal education within the context of the new South Africa" SALJ 112: 265-275

Iya, PF (2000) "Fighting Africa's poverty and ignorance through clinical legal education: Shared experiences with new initiatives for the 21 st century" International $J$ of Clinical Legal Education 1: 13-32

Iya, PF (2001) "The legal system and legal education in Southern Africa: Past influences and current challenges" J of Legal Education 51: 355-362

Kahn, E (1974) “A review of South African legal education” in D McQuoid-Mason (ed) Legal Aid in South Africa Proceedings of a conference held in the Faculty of Law, University of Natal, Durban, from 2-6 July 1973: 139-159

Kentridge, FN (1974) "Lead-in address" in D McQuoid-Mason (ed) Legal Aid in South Africa Proceedings of a conference held in the Faculty of Law, University of Natal, Durban, from 2-6 July 1973: 87-89

Kift, S (2003) “A tale of two sectors: Dynamic curriculum change for a dynamically changing profession" J of Commonwealth Law and Legal Education 2(2): 1-13 available at https:// core.ac.uk/download/pdf/10877994.pdf (accessed 5 Oct 2019)

Konop, TF (1931) "Case system - A defense" Notre Dame LR 6: 275-283

Landman, JH (1930) "The case method of studying law: A critique" available at https://www. britannica.com/biography/Roger-Bacon (accessed 5 Oct 2019)

Le Grange, L (2014) “Africanisation of curriculum” SA J of Higher Education 28(4): 1283-1294

Le Grange, L (2016) "Decolonising the university curriculum" available at https://pdfs. semanticscholar.org/4d6a/60d98a4b9aa75a7a0eb56f79ff61091cac6a.pdf (accessed 5 Oct 2019)

Letsekha, T (2013) "Revisiting the debate on the Africanisation of higher education: An appeal for a conceptual shift" Independent J of Teaching and Learning 8(1): 5-18

MacFarlane, A \& P McKeown (2008) "10 Lessons for new clinicians" International J of Clinical Legal Education 13: 63-70

Mahomed, S (2008) "United in our challenges: Should the model used in clinical legal education be reviewed?” J for Juridical Science Special Issue: 53-70

Mahomed, SH (2014) Critical Evaluation of the Practical Legal Studies Programme at the University of the Witwatersrand ( $\mathrm{PhD}$, University of the Witwatersrand)

Mahomed, S et al (2015) Clinical Law in South Africa (Durban)

Mahomed, S \& P Kruger (2009) "Teaching legal writing at the University of the Witwatersrand Law Clinic” John Marshall LJ 3: 105-134 


\section{MA (RIETTE) DU PLESSIS}

Marson J, A Wilson \& M van Hoorenbeek (2005) "The necessity of clinical legal education in university law schools: A UK perspective" International J of Clinical Legal Education 7:29-43

McQuoid-Mason, D (1974) Legal Aid in South Africa Proceedings of a conference held in the Faculty of Law, University of Natal, Durban, from 2-6 July 1973

McQuoid-Mason, D (1977) “Clinical legal education: Its future in SA” THRHR 40: 343-358

McQuoid-Mason, D (1982) An Outline of Legal Aid in South Africa (Durban)

McQuoid-Mason, D (ed) (1983) Legal Aid and Law Clinics in South Africa (Durban)

McQuoid-Mason, D (1986) "The organisation, administration and funding of legal aid clinics in South Africa" Natal University Law and Society Review 1: 139-163

McQuoid-Mason, D (2000) "The delivery of civil legal aid services in South Africa" Fordham International LJ 24(6): 111-142

McQuoid-Mason, D (2008a) "Whatever happened to the proposed South African student practice rules?” De Jure 41(3): 580-595

Mcquoid-Mason, D (2008b) "Law clinics at African universities: An overview of the service delivery component with passing references to experiences in South and South-East Asia" J for Juridical Science Special Issue: 1-23

McQuoid-Mason, D, E Ojukwu \& GM Wachira (2011) "Clinical legal education in Africa legal education and community service" in F Bloch (ed) The Global Clinical Movement Educating Lawyers for Social Justice (Oxford): 310-323

Mcquoid-Mason, D \& R Palmer (2013) African Law Clinicians' Manual available at https://ir. canterbury.ac.nz/bitstream/handle/10092/15366/African-Law-Clinicians-Manual-McQuoidMason.pdf? sequence $=2$ (accessed 5 Oct 2019)

McQuoid-Mason, DJ (2004) “Access to justice and the role of law schools in developing countries: Some lessons from South Africa: Part 1: Pre-1970 until 1990" J for Juridical Science 29(3): $28-51$

McQuoid-Mason, DJ (2005) “Access to justice and the role of law schools in developing countries: Some lessons from South Africa: Part 2: 1990 until present” J for Juridical Science 30(1): $1-16$

Mnyongani, F (2009) "Whose morality? Towards a legal profession with an ethical content that is African" SA Public Law 24: 122-134

Modiri, JM (2015) “Law’s poverty” PER 18(2): 224-273

Molefe, TO (2016) “Oppression must fall: South Africa's revolution in theory” World Policy J 33(1): 30-37

Munro, GS (2002) "How do we know if we are achieving our goals? Strategies for assessing the outcome of curricular innovation" J of the Association of Legal Writing Directors: 229-246

Murove, MF (2005) "The voice from the periphery: Towards an African business ethics beyond the Western heritage" SA J of Economic and Management Sciences 8: 339-347

Naidoo, M (2016) "Overcoming alienation in Africanising theological education" HTS Theological Studies 72(1): 1-8 available at http://www.scielo.org.za/scielo.php?script=sci_arttext\&pid =S0259-94222016000100002 $($ accessed 5 Oct 2019)

Nkosi, T (2016a) "Knowledge of the existence of discretionary powers is an implied precondition to the proper exercise of a discretion to arrest without a warrant: Motabatshindi v Minister 


\section{FORTY-FIVE YEARS OF CLINICAL LEGAL EDUCATION IN SOUTH AFRICA}

of Police (South Gauteng High Court, Johannesburg (unreported) 2014-09-26 Case No A3017/2014)" Obiter 37: 147-157

Nkosi, T (2016b) "The rules of an occupational retirement fund and the problem of defaulting employers: A reconsideration of Orion Money Purchase Pension Fund (SA) v Pension Funds Adjudicator" PER 19: 1-24

Pretorius, P (1983) "Legal aid clinics as teaching instruments" in McQuoid-Mason, D (ed) Legal Aid and Law Clinics in South Africa (Durban): 85-93

Quinot, G (2012) “Transformative legal education” SALJ 129(3): 411-433

Roach, CA (1994) "A river runs through it: Tapping into the informational stream to move students from isolation to autonomy" Arizona LR 36: 667-681

Sarkin, J (1993) "Restructuring the legal profession and access to justice: The duty of law graduates and lawyers to provide legal services" SAJHR 9: 223-236

Sayed, Y, S Motala \& N Hoffman (2017) "Decolonising initial teacher education in South African universities: More than an event" J of Education 68: 59-91

Singo, D (2016) "The role of South African university law clinics within the LLB" Stell LR 27(3): $554-574$

Singo, D \& A Raymond (2018) "Clinical legal education and social justice - a perspective from the Wits Law Clinic" Stell LR 29(2): 295-313

Smith, LF (2004) "Why clinical programs should embrace civic engagement, service learning and community based research" Clinical LR 10: 723-754

Smith, M \& T Tvaringe (2018) "From Afro-centrism to decolonial humanism and Afro-plurality. A response to Simphiwe Sesanti" New Agenda Issue 62: 41-43 available at https://ifaaza. org/2018/06/04/from-afro-centrism-to-decolonial-humanism-and-afro-plurality-a-responseto-simphiwe-sesanti/ (accessed 5 Oct 2019)

Sonsteng, JO et al (2007) "A legal education renaissance: A practical approach for the twenty-first century" William Mitchell LR 34(1): 1-118 available at https://open.mitchellhamline.edu/ wmlr/vol34/iss 1/7 (accessed 5 Oct 2019)

Spiegel, M (1987) "Theory and practice in legal education: An essay on clinical education" UCLA LR 34: 557-610

Steenhuisen, E (2006) “Goals of clinical legal education” in De Klerk, W et al (ed) Clinical Law in South Africa 2 ed (Durban): 263-280

Stuckey, R (2006-2007) “Teaching with purpose: Defining and achieving desired outcomes in clinical law courses" Clinical LR 13: 807-838

Stuckey, R et al (2007) Best Practices for Legal Education (University of South Carolina Publications, Columbia)

Sullivan, WM et al (2007) "Educating lawyers: Preparation for the profession of law" The Carnegie Foundation for the Advancement of Teaching San Francisco (The Carnegie Report)

Theophilopoulos, C \& S Tuson (2016) “'Dissecting the dead in order to safeguard the living': Inquest reform in South Africa" Stell LR 27: 161-180

Toller, FM (2010) "Foundations for a revival of the case method in civil law education" J of Civil Law Studies 21(3): 21-65 available at https://digitalcommons.law.lsu.edu/jcls/vol3/iss1/5 (accessed 5 Oct 2019) 


\title{
MA (RIETTE) DU PLESSIS
}

Van Marle, K (2002) "'No last word': Reflections on the imaginary domain, dignity and intrinsic worth” Stell LR 13: 299-308

Vawda, Y (2006) "Lost in translation: Language and diversity issues in clinical law teaching" De Jure 39(2): 295-305

Wizner, S (2001-2002) "The law school clinic: Legal education in the interests of justice" Fordham LR 70(5): 1929-1937

Woolman, S, P Watson \& N Smith (1997) “'Toto, I've a feeling we're not in Kansas anymore': A reply to Professor Motala and others on the transformation of legal education in South Africa" SALJ 114: 30-64

Zulu, P (2017) "Transformation and decolonisation of the curriculum" SAULCA: Justice through Legal Education Clinical Conference, available at https://www.saulca.co.za/conferences (accessed 5 Oct 2019)

\section{Legislation}

\author{
Attorney's Act 53 of 1979 \\ Bantu (Urban Areas) Consolidation Act 79 of 1961 \\ Group Areas Act 41 of 1950
}

